\section{How much do doctors know about the notification of infectious diseases?}

\section{Simon Voss}

Department of Public Health and Epidemiology, Odstock Hospital, Salisbury SP2 8BJ Simon Voss, MRCGP, registrar in public health medicine
The process of infectious disease notification in England and Wales is under review. ${ }^{1}$ The completeness of notification varies between areas, for different diseases, and during outbreaks. ${ }^{2-5}$ Because the reasons for this poor compliance with a statutory duty are not well understood, I investigated the knowledge and attitudes towards notification of general practitioners and junior hospital doctors in one health district.

\section{Subjects, methods, and results}

A questionnaire was sent to every principal and trainee in general practice $(n=92)$ and every junior hospital doctor $(n=62)$ in the health district of Salisbury. The questionnaire listed 16 diseases, for which respondents were asked to circle one of three options: notifiable, not notifiable, or don't know. Twelve of the diseases listed are statutorily notifiable, but four are not: AIDS (voluntarily reportable), syphilis (reported by sexually transmitted disease clinics to the Department of Health), legionnaire's disease (not notifiable but ascertained by the voluntary reports of microbiology laboratories), and red monkey disease (fictitious). Further questions asked about who has a responsibility for notification, whether this is a statutory duty, and to whom forms should be sent. The doctors were also asked to rate (on a scale of 1-5) their opinions about the value of disease notification to differen organisations. The differences between general practitioners' and junior hospital doctors' answers were analysed with the $\chi^{2}$ test with Yates's correction.

The overall response rate was $86 \%$ (general practi-

Number (percentage) of doctors who thought that they have a legal duty to notify specific diseases

\begin{tabular}{|c|c|c|}
\hline Diseases & $\begin{array}{c}\text { No }(\%) \text { of } \\
\text { general practitioners } \\
(\mathrm{n}=81)\end{array}$ & $\begin{array}{c}\text { No }(\%) \text { of } \\
\text { hospital doctors } \\
(n=51)\end{array}$ \\
\hline \multicolumn{3}{|l|}{ Statutorily notifiable: } \\
\hline Cholera & $72(89)$ & $45(88)$ \\
\hline Bacterial meningitis & $78(96)$ & $40(78)^{\star}$ \\
\hline Meningococcal septicaemia & $71(88)$ & $42(82)$ \\
\hline Plague & $66(81)$ & $47(92)$ \\
\hline Measles & $72(89)$ & $16(31) \dagger$ \\
\hline Whooping cough & $64(79)$ & $21(41) \ddagger$ \\
\hline Leptospirosis & $48(59)$ & $35(69)$ \\
\hline Lassa fever & $46(57)$ & $33(65)$ \\
\hline Viral hepatitis & $40(49)$ & $28(55)$ \\
\hline Mumps & $43(53)$ & $7(14) \S$ \\
\hline Rubella & $33(41)$ & $15(29)$ \\
\hline Viral meningitis & $31(38)$ & $14(27)$ \\
\hline \multicolumn{3}{|l|}{ Not statutorily notifiable: } \\
\hline AIDS & $33(41)$ & $23(45)$ \\
\hline Syphilis & $24(30)$ & $19(37)$ \\
\hline Legionnaire's disease & $35(43)$ & $39(76) \|$ \\
\hline Red monkey disease & $9(11)$ & $7(14)$ \\
\hline
\end{tabular}

tioners $88 \%$, hospital doctors $82 \%$ ). The number of doctors failing correctly to recognise diseases as notifiable was greatest for viral meningitis, rubella, mumps, and viral hepatitis. Junior hospital doctors were significantly less accurate than general practitioners in recognising measles, bacterial meningitis, mumps, and whooping cough, but a greater proportion of hospital doctors incorrectly identified legionnaire's disease as being notifiable (table).

Of all doctors who responded, $115(87 \%)$ knew that there is a statutory duty to notify certain infectious diseases. More than $65 \%$ of doctors were aware that those who diagnose, confirm diagnosis, or are the consultant in charge have a duty to notify. However, only $37(46 \%)$ general practitioners and $15(29 \%)$ hospital doctors knew that a doctor who suspects the diagnosis may have a duty to notify, and 29 (36\%) general practitioners and $24(47 \%)$ hospital doctors incorrectly thought that the microbiology laboratory has a duty to notify.

Both groups of doctors thought notification to be most important to the consultant for communicable disease control and national surveillance and least important to the general practitioner and individual patient.

Only $40 \%$ of responding doctors (53) were aware of where completed notification forms should be sent. Although the address is on the form, which folds into a self contained letter, anecdotal reports suggest that the forms are often put in an envelope before posting.

\section{Comment}

This survey has shown that some of the deficiencies in notification may be due to the medical profession's lack of knowledge about which diseases are notifiable. It seems likely that in many instances doctors who either suspect or make the diagnosis of a notifiable disease may not recognise it as notifiable or may be unaware of their statutory duty to notifiy. The attitude of doctors to the importance of notification to different groups may account for some disinterest in the process of notification.

Notification of an infectious disease is one of the few statutory obligations of a medical practitioner, and better instruction about it should be given to undergraduates and postgraduates. The findings of this small study are relevant to the review of the existing regulations.

I am grateful to all the general practitioners and hospital doctors in Salisbury Health Authority who responded and to Drs N Armand Smith, K Kimmance, $\mathrm{H}$ Thomas, and W Richardson and Mrs P Carthy for their help and encouragement.

Department of Health. Review of law on infectious disease control: consultation document. London: DoH, 1989.

Harvey IM, Palmer SR, Peters TJ. Meningitis: can we trust the statistics? Health Trends 1989;21:73-6.

Goldacre MJ, Miller DL Completeness of statutory notification for acute bacterial meningitis. BMF 1976;ii:501-3.

Jenkinson D. Whooping cough: what proportion of cases is notified in an epidemic? $B M \mathcal{F}$ 1983;287:185-6.

Cartwright KA, Stuart JM, Noab ND. An outbreak of meningococcal disease in Gloucestershire. Lancet 1986;ii:558-61.

Accepted 31 Ocworer 1991 